\title{
Effects of a novel probiotic, Bifidobacterium longum bv. infantis CCUG 52486 with prebiotic on the B-cell response to influenza vaccination
}

\author{
S. M. Enani, C. E. Childs, A. Przemska, C. Maidens, H. Dong, I. Rowland, K. Tuohy, S. Todd, \\ M. Gosney and P. Yaqoob \\ Department of Food and Nutritional Sciences, University of Reading, Reading RG6 6AP
}

Bifidobacterium longum bv. infantis CCUG 52486 has immunomodulatory properties, which are strongly influenced by ageing ${ }^{(1)}$. The PRIMAGE (Probiotics, Immunity and AGEing) study examined the influence of this probiotic in combination with a commercial prebiotic (BioEcolians; glucooligosaccharide) on the immune response to influenza vaccination in young and older subjects; effects of the B cell response are reported here.

58 young $(18-35 \mathrm{y})$ and 54 older $(60-85 \mathrm{y})$ subjects were treated with Bifidobacterium longum bv. infantis CCUG 52486 $\left(5 \times 10^{8} \mathrm{CFU} /\right.$ day) and glucooligosaccharide $(8 \mathrm{~g} / \mathrm{d})$ combined as a powder, or with placebo (maltodextrin) $(9 \mathrm{~g} / \mathrm{day})$ for $8 \mathrm{weeks}$ in total, with the seasonal (2010-2011 northern hemisphere) influenza vaccination being given at 4 weeks. Blood samples were taken at weeks 0, 4, 6 and 8 and peripheral blood mononuclear cells (PBMCs) were isolated and cryopreserved for analysis. B cell phenotype and expression of immunoglobulin (Ig) A and $\mathrm{G}$ were analysed by multi-parameter flow cytometry.

The absolute numbers of memory and plasma B-cells at baseline were significantly lower in old subjects compared to young subjects and there was also a significantly lower number of class switched $\operatorname{IgA}^{+}$and $\operatorname{IgG}^{+}$memory and total $\operatorname{IgA}^{+}$and $\operatorname{IgG}^{+} \mathrm{B}_{\text {-cells in older }}$ subjects. Seroconversion to all three vaccine subunits was significantly lower in the older subjects (data not shown) and successful seroconversion associated with a significantly greater increase in $\mathrm{IgG}^{+}$memory $(P<0.05)$ and total $\mathrm{IgG}^{+} \mathrm{B}$-cells $(P<0.05) 2$ weeks after vaccination. In the older subjects, treatment with the pre- and probiotic increased the number of $\mathrm{IgG}^{+}$memory B-cells and total $\mathrm{IgG}^{+}$B-cells compared with the placebo group 4 weeks after vaccination $(P<0.02$ and $P<0.05$ respectively) (Data not shown).

Table 1. B-cell profile in old and young subjects at baseline. Significant difference from young is denoted as $(*) P=0.05 ;(* *) P=0.01 ;(* * *) P<0.001$

\begin{tabular}{lrrrrr}
\hline & \multicolumn{4}{c}{ Absolute number $\times 1000 / 1 \mathrm{ml}$} & \\
\cline { 2 - 3 } & \multicolumn{2}{c}{ Young $(n=58)$} & & Old $(n=54)$ & \\
\cline { 2 - 3 } \cline { 5 - 6 } & Mean & SE & & Mean & SE \\
\hline Immature cells & 7.8 & 0.8 & 6.9 & 0.7 \\
Naive cells & 141.5 & 8.9 & $119.2^{*}$ & 8.7 \\
Memory cells & 72.3 & 4.5 & & $53.7^{* *}$ & 3.8 \\
IgA $^{+}$memory cells & 14.2 & 1.3 & & $9.7^{* *}$ & 0.8 \\
IgG $^{+}$memory cells & 12.1 & 1.5 & & $6.1^{* * *}$ & 0.7 \\
Plasma cells & 3.7 & 0.4 & & $2.0^{* * *}$ & 0.2 \\
Total IgA & 21.5 & 1.7 & & $14.1^{* * *}$ & 1.0 \\
Total IgG $^{+}$B-cells & 19.2 & 2.0 & & $10.2^{* * *}$ & 1.0 \\
\hline
\end{tabular}

In conclusion, ageing was associated with lower numbers of class switched B cells. The pre- and probiotic enhanced the production of $\mathrm{IgG}^{+}$memory and total B-cells following vaccination in old subjects. IgG expression is associated with successful seroconversion, but in older subjects, the increase in $\mathrm{IgG}$ was not sufficient to enable comparable seroconversion to the young subjects.

1. You J, Yaqoob P (2012) FEMS Immunol Med Microbiol 66, 353-362. 